\title{
Przygotowanie pacjentki do samoopieki po zabiegu mastektomii
}

\author{
Preparing the patient for self-care after mastectomy
}

MARTYNA GÓRNIEWICZ ${ }^{1}$, PAULINA ANTCZAK ${ }^{1}$

1 Studenckie Koło naukowe Nauk o Zdrowiu, Instytut Nauk o Zdrowiu PUZ we Włocławku, opiekun koła: dr. Beata Haor.

http://dx.doi.org/10.21784/IwP.2021.012

\section{Streszczenie}

Wstęp. Obecnie rak piersi plasuje się na pierwszym miejscu pod względem zachorowalności u kobiet w Polsce. W celu leczenia raka piersi stosuje się mastektomię. Przygotowanie pacjentki do samoopieki po mastektomii obejmuje nie tylko sferę fizyczną, ale także psychiczną.

Cel. Celem pracy jest analiza wybranych metod samoopieki dla pacjentki po zabiegu mastektomii.

Materiał i metody. W pracy dokonano analizy literatury poświęconej zagadnieniom opieki pielęgniarskiej nad pacjentką po zabiegu mastektomii oraz właściwym przygotowaniu jej do samoopieki.

Przegląd. Rozwojowi nowotworu piersi sprzyja szereg różnych czynników. Istotnym aspektem leczenia jest określenie stadium zaawansowania i dobranie odpowiedniej terapii. Jedną z metod postępowania leczniczego jest mastektomia. Wówczas ważnym elementem procesu terapeutycznego jest wyjaśnienie pacjentce celu zabiegu i przygotowanie jej do dalszej samoopieki.

Wnioski. Rak piersi istotnie modyfikuje jakość życia pacjentek. Po zabiegu mastektomii niezbędne jest zapewnienie prawidłowej opieki pielęgniarskiej pod względem psychicznym oraz fizycznym.Wpływa to na komfort pacjentki w trakcie pobytu, oraz po wyjściu ze szpitala.

Słowa kluczowe: samoopieka, rak piersi, mastektomia 


\section{Summary}

Introduction. Currently, breast cancer ranks first in terms of incidence in women in Poland. A mastectomy is used to treat breast cancer. Preparing a patient for self-care after mastectomy covers not only the physical but also the mental sphere.

Aim. The aim of the study is a methodological analysis of self-care for patient for mastectomy.

Materials and methods. The study analyzes the literature devoted to the issues of nursing care for a patient after mastectomy and proper preparation for self-care.

Overview. A number of factors contribute to the development of breast cancer. An important aspects of treatment is determining the stage advancement and selecting the appropriate therapy. One of therapeutic methods is mastectomy. Then, an important element of therapeutic process is explaining to the patient the purpose of the procedure and preparing her for further self-care.

Conclusions. Breast cancer significantly modifies the quality of life of patients. After the mastectomy procedure, it is necessary to provide proper mental and physical care for nursing. This affects the patient's comfort during the stay and after leaving the hospital.

Key words: self-care, breast cancer, mastectomy

\section{Wstęp}

Nowotwór piersi zajmuje drugą lokatę pod względem umieralności na nowotwory złośliwe wśród kobiet. Zdecydowanie częściej jest diagnozowany u kobiet. $\mathrm{W}$ gronie mężczyzn rak piersi stanowi $1 \%$ wszystkich zlokalizowanych nowotworów [1]. Przygotowanie do zabiegu mastektomii obejmuje ciało i psychikę pacjentki. Przed planowanym zabiegiem należy przeprowadzić z pacjentką rozmowę $\mathrm{w}$ trakcie której będzie miała możliwość na zadanie nurtujących ją pytań. Zespół terapeutyczny powinien wyjaśnić chorej wszelkie wątpliwe elementy i zapewnić o swojej opiece. Pozwoli to uspokoić pacjentkę i wyrównać jej nastrój. Osoba, która będzie poddana zabiegowi mastektomii musi wiedzieć jak zmieni się jej wygląd, a także jak będzie wyglądać opieka w trakcie jaki po zabiegu. Oprócz przygotowania psychicznego, do zabiegu trzeba przygotować chorą fizycznie. Zatem tuż przed planowaną 
amputacją należy wykonać toaletę ciała, jeżeli pacjentka będzie miała problem z samodzielnym wykonaniem czynności higienicznych, zawsze może liczyć na pomoc ze strony personelu pielęgniarskiego. W przypadku, gdy oprócz choroby nowotworowej współistnieją inne dolegliwości między innymi ze strony układu krwionośnego należy założyć opaski uciskowe. Pozwoli to uniknąć wystąpienia zakrzepów i zatorów [2].

\section{Przegląd}

Choroba nowotworowa piersi przenosi się drogą krwionośną oraz chłonną. Zazwyczaj w pierwszej kolejności zajmowane są regionalne węzły chłonne, czyli przymostkowe i pachowe. Poprzez naczynia krwionośne nowotwór piersi może przenosić się do prawie wszystkich narządów. Większość przerzutów odległych diagnozuje się w układzie kostnym, wątrobie oraz opłucnej [3].

Na rysunku 1. przedstawiono zachorowalność na nowotwory u kobiet w roku 2018 w województwie kujawsko-pomorskim [4].

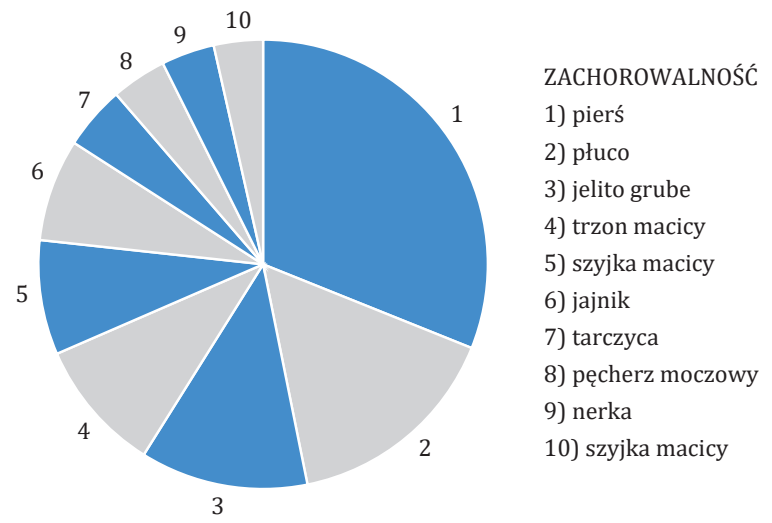

Ryc. 1. Zachorowalność na nowotwory u kobiet w roku 2018 w województwie kujawsko-pomorskim. Źródło: Krajowy Rejestr Nowotworów [4]

Dane, pochodzące z Krajowego Rejestru Nowotworów z 2018 roku, przedstawiają zachorowalność na nowotwory u kobiet w 2018 roku w województwie kujawsko-pomorskim. 
Z rysunku 1. wynika, że rak piersi jest najczęściej występującym nowotworem u kobiet $\mathrm{w}$ województwie kujawsko-pomorskim i dotyczy $21,1 \%$ badanych. Często występującymi nowotworami u kobiet są również rak płuca $(10,7 \%)$, rak jelita grubego $(8,2 \%)$, rak trzonu macicy $(6,5 \%)$.

Rysunek 2. przedstawia zachorowalność oraz strukturę zgonów na nowotwory u kobiet w Polsce w 2018 roku [4].

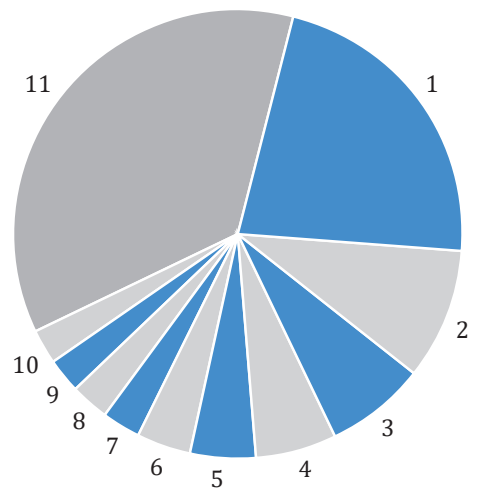

ZACHOROWALNOŚĆ

1) pierś

2) płuco

3) trzon macicy

4) okrężnica

5) jajnik

6) tarczyca

7) szyjka macicy

8) odbytnica

9) nerka

10) trzustka

11) inne

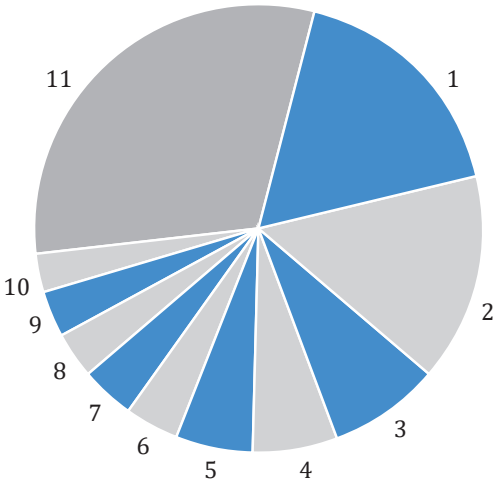

STRUKTURA ZGONÓW

1) płuco

2) pierś

3) okrężnica

4) jajnik

5) trzustka

6) trzon macicy

7) żołądek

8) szyjka macicy

9) mózg

10) odbytnica

11) inne

Ryc. 2. Zachorowalność oraz struktura zgonów na nowotwory u kobiet w Polsce w 2018 roku.Źródło: Krajowy Rejestr Nowotworów [4].

Dane, pochodzące z Krajowego Rejestru Nowotworów z 2018 roku, przedstawiają zachorowalność oraz strukturę zgonów na nowotwory u kobiet w Polsce w 2018 roku. 
Z rysunku 2. wynika, że zachorowalność na raka piersi jest największa wśród kobiet w Polsce, jednak nie jest to najczęstsza przyczyna zgonów. Do najczęstszej przyczyny zgonów należy rak płuc, jednak zachorowalność jest mniejsza niż w przypadku raka piersi.

Na powstanie raka piersi mają wpływ następujące czynniki wysokoprocentowy alkohol, dieta z dużą ilością tłuszczy nasyconych, otyłość (szczególnie przy otyłości brzusznej i w okresie pomenopauzalnym). Ważne jest również oddziaływanie estrogenów na gruczoł piersiowy. Im dłużej estrogeny oddziałują na gruczoł piersiowy, tym większe ryzyko powstania raka piersi. Przyczynia się do tego wczesna pierwsza miesiączka oraz późny okres menopauzalny, urodzenie pierwszego dziecka po 30 r. ż., oraz brak dzieci. U kobiet młodych bardzo ważne jest unikanie napromieniowania. Promieniowanie ma związek z wystąpieniem 1\% przypadków raka piersi. Profilaktyka pierwotna dotyczy zatem ograniczenia spożywania alkoholu, utrzymanie prawidłowej masy ciała, zdrowe odżywianie, aktywność fizyczna, urodzenie dziecka przed 30 rokiem życia oraz unikanie napromieniowania [5].

W profilaktyce wtórnej najczęściej wykorzystywanym badaniem jest badanie mammograficzne. Według badań przeprowadzonych w USA umieralność na raka piersi jest mniejsza o ok. 15\% bez względu na wiek kobiet dzięki mammografii. W Polsce kobiety w wieku 50-69 lat są objęte bezpłatnym badaniem dzięki Populacyjnemu Programowi Wczesnego Wykrywania Raka Piersi. U kobiet z grupy wysokiego ryzyka mammografia jest zalecana co roku od około 35 roku życia. Do grupy wysokiego ryzyka zalicza się kobiety, u których wystąpiły 2 zachorowania na raka piersi lub rozpoznano raka metachronicznego wśród krewnych pierwszego lub drugiego stopnia, siostra lub mama zachorowała przed 40 rokiem życia [5].

W profilaktyce raka piersi konieczne jest również wykonywanie samobadania piersi. Samobadanie powinno być wykonywane co miesiąc. Jest najprostszym badaniem pozwalającym na wykrycie raka piersi. Zdarza sie, że poprzez samobadanie można wykryć raka piersi niewidocznego dla badań obrazowych [6]. 
Ultrasonografii (USG) nie stosuje się w badaniach profilaktycznych, jednak jest pomocna w potwierdzeniu już wcześniej wykrytego raka piersi innymi metodami [6].

Tabela 1. Klasyfikacja nowotworów piersi [w oparciu o: Jassem J., Krzakowski M., Bobek-Billewicz B. Breastcancer. OncolClinPract 2018:216 [7].

\begin{tabular}{|c|c|}
\hline Rodzaj zmian & Jednostka chorobowa \\
\hline $\begin{array}{l}\text { Łagodne zmiany } \\
\text { proliferacyjne }\end{array}$ & $\begin{array}{l}\text { Gruczolistość stwardniająca, } \\
\text { Gruczolistośćapokrynowa, } \\
\text { Blizna promienista/złożona zmiana } \\
\text { stwardniająca, } \\
\text { Gruczolak cewkowy, } \\
\text { Gruczolak przewodowy. }\end{array}$ \\
\hline $\begin{array}{l}\text { Wewnątrzprzewodowe } \\
\text { zmiany proliferacyjne }\end{array}$ & $\begin{array}{l}\text { Zwykła hiperplazja przewodowa, } \\
\text { Zmiany walcowatokomórkowe, } \\
\text { Atypowa hiperplazja przewodowa. }\end{array}$ \\
\hline Zmiany prekursorowe & $\begin{array}{l}\text { Rak przewodowy in situ, } \\
\text { Neoplazja zrazikowa. }\end{array}$ \\
\hline Zmiany brodawkowe & $\begin{array}{l}\text { Brodawczak wewnątrzprzewodowy: } \mathrm{z} \text { atypową } \\
\text { hiperplazją, z rakiem przewodowym in situ, } \\
\text { z rakiem zrazikowym in situ, } \\
\text { Wewnątrzprzewodowy rak brodawkowy, } \\
\text { Lity rak brodawkowy in situ. }\end{array}$ \\
\hline Naciekający rak piersi & $\begin{array}{l}\text { Rak mikroinwazyjny, } \\
\text { Rak naciekający bez specjalnego typu, } \\
\text { Rak naciekający zrazikowy, } \\
\text { Rak cewkowy, } \\
\text { Rak sitowaty, } \\
\text { Rak śluzowy, } \\
\text { Rak metaplastyczny, } \\
\text { Rak rdzeniast. }\end{array}$ \\
\hline $\begin{array}{l}\text { Nowotwory } \\
\text { mezenchymalne }\end{array}$ & $\begin{array}{l}\text { Guzkowe zapalenie powięzi, } \\
\text { Naczyniak, } \\
\text { Mięsak naczyniowy. }\end{array}$ \\
\hline $\begin{array}{l}\text { Nowotwory } \\
\text { włóknistonabłonkowe }\end{array}$ & $\begin{array}{l}\text { Gruczolakowłókniak, } \\
\text { Guz liściasty: łagodny, graniczny, złośliwy. }\end{array}$ \\
\hline
\end{tabular}


Leczenie chorych na raka piersi odbywa się metodą leczenia skojarzonego. W jego skład wchodzą metody miejscowe- chirurgia i radioterapia, a także metody ogólnoustrojowe, czyli chemioterapia. Wybór metody leczenia jest zależny od stanu pacjentki. W trakcie zabiegu operacyjnego może zostać zastosowana koncepcja leczenia oszczędzającego. Wówczas stosuje się zabieg chirurgiczny podczas którego zostaje usunięty guz z marginesem zdrowej tkanki, a następnie pierś zostanie pooperacyjnie napromieniowana. Drugą metodą wykorzystywaną w leczeniu operacyjnym jest radykalna amputacja piersi. Wskazaniem do tego typu zabiegu jest stopień zaawansowania nowotworu, a także brak kwalifikacji do leczenia oszczędzającego[3]. Wśród radykalnej amputacji piersi można wyodrębnić różne metody przeprowadzenia zabiegu. Można go dokonać za pomocą amputacji prostej lub podskórnej. Zabieg przeprowadzany metodą amputacji prostej polega na usunięciu całej piersi wraz z powięzią mięśnia piersiowego większego i kompleksem otoczka-brodawka. Natomiast podczas przeprowadzania amputacji podskórnej usunięta zostaje tkanka gruczołowa, pozostawiona zostaje skóra, otoczka brodawki oraz brodawka. Dodatkowo istnieje możliwość zastosowania metod: Maddena, Pateya oraz Halsteda[8]. Amputacja z zastosowaniem techniki Maddena polega na wycięciu gruczołu piersiowego i pozostawieniu mięśni piersiowych. Metoda Pateya w dzisiejszych czasach jest stosowana rzadko. Obszar operacji obejmuje gruczoł piersiowy, powięź mięśnia piersiowego większego i mniejszego, a także węzły chłonne pachowe. W przypadku, gdy ma miejsce naciekanie na mięsień piersiowy większy wskazaną metodą amputacji jest koncepcja Halsteda. Wówczas mięsień piersiowy większy jest usuwany pomimo ewentualnego zmniejszenia guza na skutek wstępnej hormono- lub chemioterapii [9].

Przygotowując pacjentkę do zabiegu mastektomii należy zwrócić szczególną uwagę, aby nie ograniczać się jedynie do sfery fizycznej. Psychika pacjentki jest równie ważna. Już sama choroba nowotworowa piersi jest dla pacjentki traumatycznym przeżyciem. Zabieg mastektomii może dodatkowo obciążyć sferę psychiczną. Dlatego, podczas przy- 
gotowywania pacjentki do zabiegu mastektomii konieczne jest dokładne wytłumaczenie na czym ten zabieg polega. Warto także poruszyć kwestię dalszego funkcjonowania chorej, już po przebytym zabiegu. Przygotowanie w sferze fizycznej wiąże się z optymalizacją ogólnego stanu zdrowia. Podczas tego procesu szczególną uwagę zwraca się na układ krążenia, pokarmowy i oddechowy. Przygotowanie układu pokarmowego do zabiegu obejmuje poinformowanie pacjentki o konieczności wstrzymania przyjmowania pokarmów w postaci stałej i płynnej na co najmniej od 6 do 8 godzin przed rozpoczęciem zabiegu. Kolejnym elementem jest toaleta całego ciała, łącznie z miejscem przeznaczonym do amputacji. Ma to zapobiec ewentualnemu zakażeniu rany. Po zakończeniu zabiegu mastektomii i stabilizacji stanu, pacjentka wraca na oddział. Wówczas należy zadbać o prawidłowe ułożenie chorej w łóżku. Pacjentka powinna przebywać w pozycji półsiedzącej z uniesieniem kończyny po stronie operowanej. Można do tego wykorzystać podpórkę lub odpowiednio przystosowaną poduszkę. Pozwoli to zapobiec powstawaniu obrzęków.
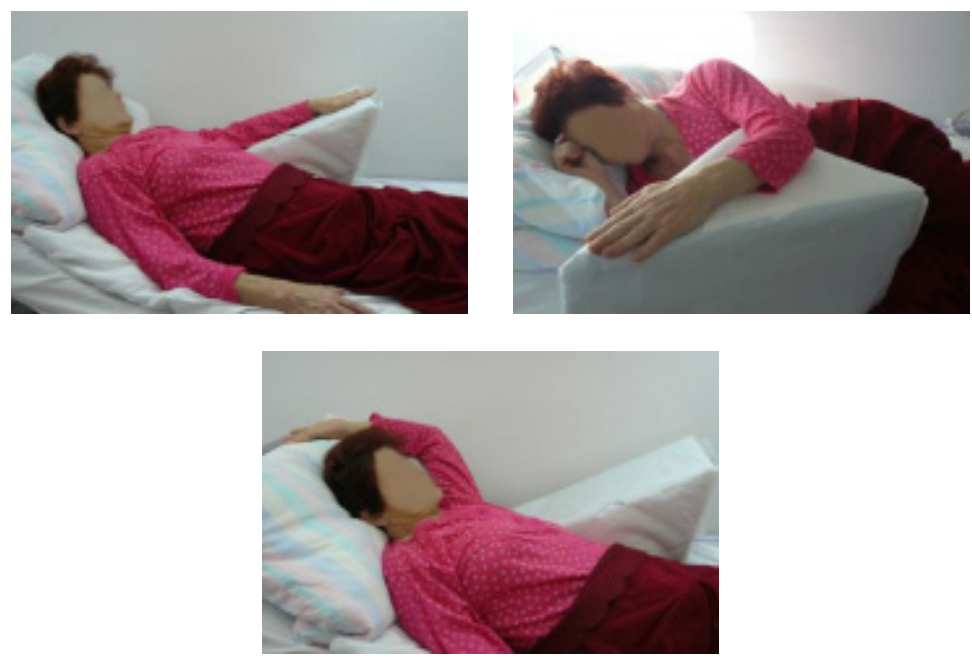

Ryc. 3. Zalecane pozycje ułożeniowe po zabiegu mastektomii.

[Opuchlik A. Informator dla kobiet po leczeniu raka piersi. Świętokrzyskie Centrum Onkologii. Zakład Rehabilitacji. 2016;4-9:11-12]. 
Oprócz prawidłowego ułożenia pacjentki, należy zwrócić uwagę na rozkład drenów i ich drożność, a także na ilość wydzieliny. Opatrunek na ranie również powinien być pod stałą kontrolą. Konieczne jest sprawdzanie czy dobrze przylega do rany i czy jest suchy. Pacjentce należy poradzić, aby oddychała głęboko. Od czasu do czasu można ją zachęcić do głębokiego kaszlu. Pozwoli to na uniknięcie przekrwienia płuc, które może wystąpić w skutek ucisku opatrunku na klatkę piersiową. Ręka pacjentki znajdująca się po operowanej stronie powinna przez całą dobę być ułożona na podwyższeniu. Nie wolno na niej mierzyć ciśnienia, wykonywać iniekcji oraz pobierać krwi. Po upływie kilku godzin od momentu operacji należy poinformować pacjentkę, że powinna zacząć ćwiczyć rękę. Początkowo ćwiczenia ograniczają się do zginania i prostowania palców. Można także zachęcić do poruszania przedramieniem i obracania dłoni. Pacjentka powinna zostać poinformowana, że wykonywanie ćwiczeń pozwoli na odzyskanie sprawności fizycznej ręki. Pomoże także zniwelować ryzyko powstania przykurczy mięśni i stawów. Po upływie kilku dni do pacjentki na rehabilitację powinien przychodzić wykwalifikowany fizjoterapeuta, który wyjaśni jej istotę i prawidłowy sposób wykonywania ćwiczeń. Pacjentka powinna także uzyskać informacje jak wykonywać prawidłowo ćwiczenia w warunkach domowych. Podczas pobytu chorej w szpitalu personel medyczny powinien zachęcać ją do zapoznania się z wyglądem rany pooperacyjnej. Pozwoli to na oswojenie się chorej z nowym wyglądem gruczołu piersiowego. Należy także przeprowadzić rozmowę edukacyjną z pacjentką na temat dalszego postępowania $\mathrm{z}$ raną $\mathrm{w}$ warunkach domowych. Pielęgniarka powinna wyjaśnić chorej jak prawidłowo pielęgnować miejsce po operacji i jakich preparatów pielęgnacyjnych najlepiej używać, a także jak wykonywać zmianę opatrunku [2]. Podczas wypisu pacjentki do domu konieczne jest poinstruowanie pacjentki o kolejnym terminie i miejscu kontroli rany pooperacyjnej. Należy również udzielić wskazówek dotyczących dalszej rehabilitacji i kontynuacji leczenia onkologicznego. Pacjentka powinna zostać poinformowana o możliwości kontaktu z istniejącymi grupami wsparcia, a także o możliwym protezowaniu [10]. 
Udział w grupie wsparcia dla dużej części pacjentek jest bardzo pomocny. Do takiej grupy zalicza się Federacja Stowarzyszeń „Amazonki”. W tej organizacji pacjentki mogą otrzymać niezbędne wsparcie psychiczne i pomoc w akceptacji nowego wyglądu. Pacjentka w domu powinna nadal kontynuować ćwiczenia poznane podczas pobytu w szpitalu. W miarę upływu czasu po przebytym zabiegu intensywność ćwiczeń może się zwiększać. Zawsze jednak wszelka aktywność musi być dostosowana do aktualnego stanu pacjentki. Po wygojeniu się rany pacjentka powinna zaopatrzyć się w protezę piersi. Musi być jednak odpowiednio dobrana i dopasowana. Oprócz rehabilitacji fizycznej, konieczne jest włączenie terapii psychofizycznej. Dzięki temu psychika pacjentki będzie w lepszej kondycji co wpłynie na akceptację wyglądu i zaklimatyzowanie się w społeczeństwie. Wzmocni to poczucie własnej wartości [11]. $\mathrm{W}$ procesie samoopieki niezwykle ważne jest, aby osoba po mastektomii otrzymała wsparcie i zrozumienie ze strony najbliższej rodziny. Dodatkowo akceptacja choroby sprawi, że pacjentce będzie łatwiej w powrocie do dawnej sprawności i normalnego funkcjonowania [12].

W planowaniu opieki pielęgniarskiej nad pacjentką po zabiegu mastektomii zastosowanie znajduje model Dorothy Orem. Zgodnie z którym pacjenci, którzy nie są zdolni do samodzielnego dbania o swoje zdrowie wymagają opieki ze strony innych. Pacjentka, która przebywa na oddziale po przebytym zabiegu mastektomii powinna otrzymać od personelu pielęgniarskiego jak największe wsparcie i pomoc. Dzięki temu zmniejszą się odczuwalne przez nią skutki interwencji chirurgicznej. Pielęgniarka powinna dysponować umiejętnościami, które umożliwiają rozpoznanie stanu pacjentki i dobór odpowiednich meto terapeutycznych indywidualnie do potrzeb pacjentek. Postępując zgodnie z założeniami modelu D. Orem opieka nad pacjentką po przebytym zabiegu amputacji piersi będzie się odbywać na bazie obserwacji oraz analizy dokumentacji pielęgniarskiej a także rozmowy przeprowadzonej z pacjentką. Tak więc sposób opieki będzie się opierał między innymi na systemie wspierająco-uczącym, czyli personel będzie edukował pacjentkę o najlepszych dla niej możliwościach samoopieki w warun- 
kach domowych. Sytuacja w której pacjentka jest po zabiegu mastektomii wymaga utworzenia indywidualnego planu opieki, który będzie zawierał procedury zapewniające pacjentce bezpieczeństwo i uchroni ją przed ewentualnymi powikłaniami. Będzie także zobowiązywał personel pielęgniarski do czuwania nad prawidłowym procesem gojenia się rany pooperacyjnej i powrotu pacjentki do jak najwyższego stopnia funkcjonalności [10].

\section{Zalecenia po zabiegu mastektomii [13]:}

- unikanie urazów oraz wysiłku kończyny górnej po stronie, gdzie pierś była operowana (wysiłek oraz urazy mogą spowodować obrzęk limfatyczny),

- w czasie wypoczynku stosować odpowiednie pozycje ułożeniowe

- zgłaszać lekarzowi niepokojące objawy (zaczerwienienie, obrzęk, gorączka, dreszcze),

- nie mierzyć ciśnienia krwi oraz nie wykonywać żadnych zabiegów na ręce po stronie operowanej piersi,

- wykonywać masaż kończyny po stronie operowanej piersi (2 razy dziennie po 10 minut),

- wykonywać ćwiczenia gimnastyczne z protezą piersi (3 razy dziennie przez około 15 minut),

- wykonywanie spokojnej aktywności fizycznej (spacery, joga),

- unikać zbyt ciepłych oraz zbyt niskich temperatur (opalanie się, długie spacery zimą),

- dobór luźnej odzieży (biustonosz nie może uciskać klatki piersiowej ani barku),

- zaleca się pracę siedzącą (w czasie przerw korzystne będzie unoszenie kończyny oraz jej potrząśnięcie),

- zastosowanie automasażu kończyny po stronie operowanej piersi (głaskanie, wyciskanie, ugniatanie, rozcieranie, oklepywanie). 


\section{Wnioski}

1. Przed planowanym zabiegiem mastektomii należy zwrócić uwagę na prawidłowe przygotowanie osoby chorej od strony fizycznej oraz psychicznej.

2. Regularna rehabilitacja, kontakt z grupami wsparcia i różnego rodzaju stowarzyszeniami pomagają $\mathrm{w}$ znacznym stopniu kobiecie po amputacji piersi w akceptacji swojego nowe wyglądu.

3. Stosowanie się do czynności zalecanych po zabiegu mastektomii umożliwia zminimalizowanie ryzyka wystąpienia powikłań oraz gwarantuje szybszy powrót do sprawności fizycznej.

\section{Bibliografia/ Bibliography:}

1. Ośmiałowska E., Świątoniowska N., Homętowska H. Jakość życia pacjentek z rozpoznaniem nowotworu piersi. Paliative Medicine in Practice 2018;12,3:144.

2. Ponichtera P., Borusiewicz A., Zabielska P., Pawłowski M. Seria: Zeszyty Naukowe nr 43. Wydawnictwo Wyższej Szkoły Agrobiznesu w Łomży. Łomża 2009:50-53

3. Jeziorski A. Onkologia. Podręcznik dla pielęgniarek. Państwowy Zakład Wydawnictw Lekarskich, Warszawa 2005:11-101.

4. Wojciechowska U.,Didkowska J., Michałek I.,Olasek P.,Ciuba A. Nowotwory złośliwe w Polsce w 2018 roku. Krajowy Rejestr Nowotworów. Warszawa $2020 ; 7: 35$

5. Tkaczuk-Włach J., Sobstyl M., Jakiel G. Rak piersi - znaczenie profilaktyki pierwotnej i wtórnej. Przegląd Menopauzalny 2012:343-345.

6. Kornafel J. Rak piersi. Centrum Medyczne Kształcenia Podyplomowego. Warszawa 2011:10.

7. Jassem J., Krzakowski M., Bobek-Billewicz B. Breastcancer. OncolClinPract 2018:216.

8. http://onkologia.org.pl/rak-piersi-kobiet/\#a dostęp dnia 02.03.2021 r. 
9. Opuchlik A., Włoch A., Biskup M., Ridan T., Wróbel P., Jonak R., Curyło M. Metody leczenia onkologicznego i chirurgicznego oraz postępowanie fizjoterapeutyczne u kobiet z rakiem piersi. Rehabilitacja Medyczna (MedRehabil) 2018;22,1:38-48.

10. Piotrowska R., Książek J., Falba A. Model Dorothy Orem w opiece nad pacjentką z rakiem piersi. Problemy Pielęgniarstwa 2008;16(4):352-358.

11. http://onkologia.org.pl/rak-piersi-kobiet/\#s dostęp dnia 02.03.2021 r.

12. Sosnowska-Bąk M., Oleszko K., Plinta-Skrzypulec V. Adaptacja psychologiczna dojrzałych kobiet w pierwszych dobach po zabiegu mastektomii. Przegląd Menopauzalny 2013;2:120-124

13. Opuchlik A. Informator dla kobiet po leczeniu raka piersi. Świętokrzyskie Centrum Onkologii. Zakład Rehabilitacji. 2016;4-9:11-12. 